\title{
Study on Design of Truncated Mooring Line with Static Similarity in Model Test Basins
}

\author{
Yun-Ho Kim, Byoung-Wan Kim and Seok-Kyu Cho* \\ "Offshore Plant Research Institute, Korea Research Institute of Ships and Ocean(KRISO), Daejon, Korea
모형수조에서 정적 상사성을 지닌 절단계류선 모델링에 관한 연구
김윤호* 김병완 $\cdot$ 조석규
"한국해양과학기술원 부설 선박해양플랜트연구소 해양플랜트연구부

KEY WORDS: Truncated mooring line for model test 모형시험용 절단계류선, Deepwater cean engineering basin 심해공학수조, Finite element method 유한요소법, Static offset test 정적 변위 테스트, Static similarity 정적 상사성

\begin{abstract}
In this study, a series of numerical simulations was conducted in order to design a truncated mooring line with a static similarity to the prototype. A finite element method based on minimizing the potential energy was utilized to describe the dynamics of mooring lines. The prototype mooring lines considered were installed at a water depth of 1,000 $\mathrm{m}$, whereas the KRISO ocean engineering basin (OEB) in Daejeon has a water depth of $3.2 \mathrm{~m}$, which represents $192 \mathrm{~m}$ using a scaling of 1:60. First, an investigation for the design of the truncated mooring line was carried out to match the static characteristics of the KRISO Daejeon OEB environment. Then, the same procedure was performed with the KRISO new deepwater ocean engineering basin (DOEB) that is under construction in Busan. This new facility has a water depth of $15 \mathrm{~m}$, which reflects a real scale depth of $900 \mathrm{~m}$ considering the 1:60 scaling factor. A finite element method was used to model the mooring line dynamics. It was found that the targeted truncated mooring line could not be designed under the circumstances of the KRISO OEB with any material properties, whereas several mooring lines were easily matched to the prototype under the circumstances of the KRISO DOEB.
\end{abstract}

\section{1. 서 론}

지속적인 에너지 수요 증가와 육상 및 연안에서의 에너지 개발 이 포화상태에 이름에 따라 해저 석유 개발 수심은 점점 더 깊어 지는 상황이다. 그러나 실험수조의 경우 깊이, 폭의 물리적 제약 으로 인해 실제 계류선과 기하학적 및 동역학적 상사성을 지닌 모형 계류선 투입이 상당히 어렵다. 현재 한국해양과학기술원 부 설 선박해양플랜트연구소(Korea Research Institute of Ships and Ocean Engineering, KRISO)에서 운용 중인 해양공학수조(Ocean Engineering Basin, $\mathrm{OEB})$ 는 수심이 최대 $3.5 \mathrm{~m}$ 이며, 예로써 1:60 축 적비 모형시험을 수행한다면 $210 \mathrm{~m}$ 해역까지 모사할 수 있다. 현 재 동 기관에서는 심해공학을 보다 체계적이고 엄밀하게 연구할 수 있는 심해공학수조(Deepwater Ocean Engineering Basin, DOEB) 를 건설 중이다. 본 시설은 수조 수심을 최대 $15 \mathrm{~m}$ 까지 조절 가능 하며, 수조 가운데에는 $50 \mathrm{~m}$ 원통형 피트가 자리 잡고 있어 심해 에 설치되는 해양구조물의 계류선 및 라이저 연구에 큰 역할을
수행할 것으로 기대된다. 그럼에도 불구하고 극 심해에 설치되는 계류시스템을 완전히 상사시키기에는 한계가 있다. 이를 극복하 고자 심해에서 운용되는 계류시스템의 안정성 평가를 위한 선행 연구는 다음과 같다.

Bernitsas et al.(1999)은 심해 계류선 모사를 위한 세 가지 방안으 로써 실 해역에서의 실험(Natural model basin), 아주 작은 축척 비를 지닌 모형 시험(Ultra small scale model test)과 수동적 및 능동적 하이브리드 시험(Passive/Active hybrid system)을 제안했다. 이 중 세 번째 방안이 실제 기하학적 상사는 맞추기 어렵지만, 원형시스 템과 정적, 동적 상사를 지닌 절단계류선을 설계하여 이를 수조 시험에 활용하는 방안이다. ITTC(International Towing Tank Conference)는 이 주제에 대한 지침서를 2002년부터 3년 간격으로 출판하였다(ITTC, 2002, 2005). 특히 2002년 지침서에는 노르웨이 MARINTEK(Norwegian Marine Technology Research Institute)에서 수심 1,500 3,000m에 투입되는 계류선에 대한 체계적 정리가 포함 되었다(Stansberg et al., 2002). 현수식(Catenary) 계류선을 지닌

Received 8 May 2017, revised 11 May 2017, accepted 17 July 2017

Corresponding author Yun-Ho Kim: +82-42-866-3959, yunhokim@kriso.re.kr

(C) 2017, The Korean Society of Ocean Engineers

This is an open access article distributed under the terms of the creative commons attribution non-commercial license (http://creativecommons.org/licenses/by-nc/3.0) which permits unrestricted non-commercial use, distribution, and reproduction in any medium, provided the original work is properly cited. 
FPSO(Floating Production Storage and Offloading)와 반 인장식 (Semi-Taut) 계류선을 지닌 반잠수식 구조물에 대한 절단계류선 설계도 수행되었으며(Waals and van Dijk, 2004), 계류선 길이 인자 비율을 시작으로 특성 수치들의 비율로써 절단계류선 설계에 대한 최적화가 이루어졌다. 또한 절단계류수심이 원형시스템에 비해 $1 / 4,1 / 8,1 / 12$ 인 경우 정적 및 동적 상사를 지닌 모형시험용 절단계 류선 설계에 대한 연구가 수행되었으며(Baarholm et al., 2007), 여 기서 수심 비율 $1: 8$ 이하에서는 절단계류선 설계가 용이하지 않다 고 정리되었다. 이 외에도 해양공학수조를 운용하는 모든 기관이 심해에 투입되는 계류선에 대한 고찰과 대안 방안이 연구되었으 나, 현재까지 지배적인 방법론은 도출되지 않은 상황이다.

본 논문에서는 수심 $1,000 \mathrm{~m}$ 에 설치되는 현수식 계류선에 대 하여 정적 상사성을 만족하는 절단계류선을 KRISO 해양공학수 조 및 심해공학수조 조건에서 설계하였다. 수조시험의 용이성 을 위해서 단일 제원으로 절단계류선 모사가 가능한지를 검토 하였다. 구조물의 Fairlead위치를 종 방향으로 이동시키며 부유 체에 작용하는 전체 계류력 및 각 계류선에 걸리는 장력을 계 산하였다. 계류반경은 각 수조별 최대한으로 설정한 다음, 계류 선 길이, 물 속 중량, 축 강성을 변화시키며 발생되는 복원력과 계류선 장력이 원형시스템의 결과와 일치하는지를 검토하였다.

\section{2. 유한요소법을 이용한 계류선 정식화}

중량과 축 강성을 고려하여 계류선에 대한 최소에너지 원리를 이용한 유한요소법 정식화는 이전 연구에서 수행되었다(Kim et al., 2010). 이 중에서 핵심적인 부분만 발췌하면 다음과 같다. Fig. 1 에서 $T$ 는 물체고정좌표계에서 축 방향 장력을 의미한다. 국부좌 표계 $(x, y, z)$ 는 단위 요소의 길이 방향을 양의 $x$ 축으로 하는 카르테 시안 좌표계(Cartesian coodinates)가 정의되며, 이는 변환 행렬을 통해 전체좌표계 $\left(x_{g}, y_{g}, z_{g}\right)$ 로 변환되어 전체 복원력 합력을 구하게 된다. $l$ 은 요소별 상대적 크기를 정의하기 위해 사용자가 지정해주 는 기준선 길이이다. $d s$ 는 단위요소의 미소 길이, $\vec{r}$ 은 국부좌표계 에서 위치 벡터를 의미한다. $w$ 는 단위 요소의 길이 당 수중중량, $\left(f_{x 1}, f_{y 1}, f_{z 1}\right)$ 은 1 번 절점에 걸리는 단면력, $\left(f_{x 2}, f_{y 2}, f_{z 2}\right)$ 은 2 번 절 점에 걸리는 단면력이다. 단위 요소의 각 방향에 대한 변위는 $u_{x}, u_{y}, u_{z}$ 이다. 위치 벡터와 자코비안(Jacobian)은 각 각 식 (1), (2) 와 같다.

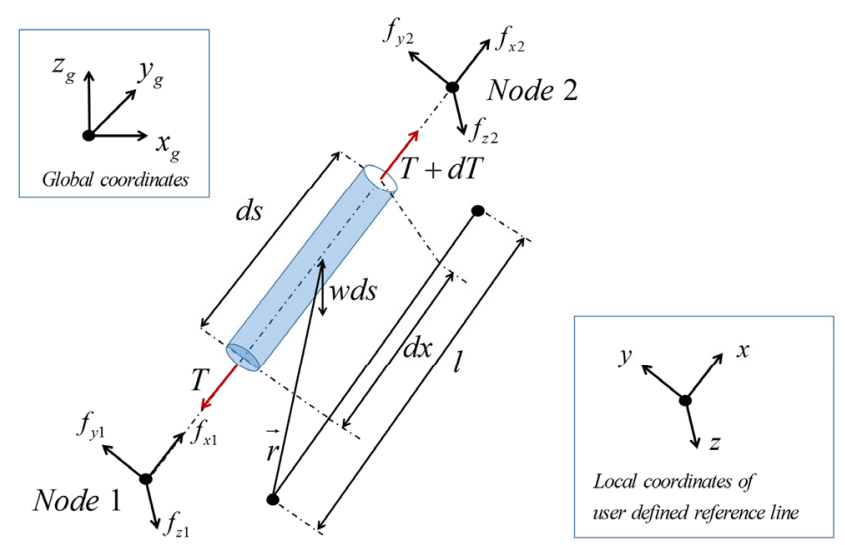

Fig. 1 Coordinates and definitions of a free element $\mathrm{T}$

$$
\begin{aligned}
& \vec{r}=\left(x+u_{x}, u_{y}, u_{z}\right) \\
& J=\frac{d s}{d x}=\frac{|\overrightarrow{d r}|}{d x}=\sqrt{\left(1+\frac{\partial u_{x}}{\partial x}\right)^{2}+\left(\frac{\partial u_{y}}{\partial x}\right)^{2}+\left(\frac{\partial u_{z}}{\partial x}\right)^{2}}
\end{aligned}
$$

위의 정의를 기반으로 포텐셜 에너지와 변형 에너지, 운동 에너 지와 외력을 고려한 최소 에너지 원리를 적용한다. 또한 요소 길이 에 대한 적합 조건을 추가하여 지배방정식은 식 (3)으로 도출된다. $\left\{u_{e}\right\}$ 는 단위 요소에 대한 12자유도 변위 벡터이며 식 (4)와 같다. $\dot{u}_{B}, u_{B}$ 는 각 각 Fairlead에서의 6자유도 속도 및 변위로써 계류선 모델링 시 구속조건으로 작용된다. $\left[M_{e}\right],\left[K_{e}\right]$ 는 단위 요소에 대한 관성, 복원력 행렬로써, Kim et al.(2010, 2013)에 자세히 기술되어 있다. 라그랑지 승수인 $\lambda$ 에 곱해지는 벡터 $\{B\}$ 는 식 (5)와 같으며, $[R]$ 은 좌표계 변환 행렬로써, 식 (6)을 만족해야 한다. $\left\{f_{e}\right\}$ 는 두 절점에 작용하는 단면력 벡터로써 식 (7)과 같이 표현되며, $\left\{f_{w g e}\right\}$ 는 중량에 의한 힘으로써 식 (8)과 같다. 마지막으로 요소 길이에 대한 적합조건 방정식은 식 (9)로 구성되며, 식 (3)과 식 (9)가 연립 되어 계류선 동역학을 계산하게 된다.

$$
\begin{aligned}
& {\left[M_{e}\right]\left\{\ddot{u}_{e}\right\}+\left[K_{e}\right]\left\{u_{e}\right\}+\{B\} \lambda=[R]\left\{f_{w g e}\right\}+\left\{f_{e}\left(\dot{u_{B}}, u_{B}\right)\right\}}
\end{aligned}
$$

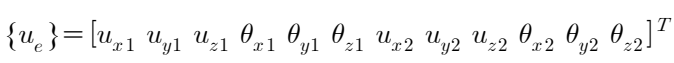

$$
\begin{aligned}
& \{B\}=\frac{2}{J+1}\left[\begin{array}{llllllllllll}
-1 & 0 & 0 & 0 & 0 & 0 & 1 & 0 & 0 & 0 & 0 & 0
\end{array}\right]^{T}+\frac{1}{(J+1) l} \\
& {\left[\begin{array}{cccccccccccc}
1 & 0 & 0 & 0 & 0 & 0 & -1 & 0 & 0 & 0 & 0 & 0 \\
& 1 & 0 & 0 & 0 & 0 & 0 & -1 & 0 & 0 & 0 & 0 \\
& & 1 & 0 & 0 & 0 & 0 & 0 & -1 & 0 & 0 & 0 \\
& & & 0 & 0 & 0 & 0 & 0 & 0 & 0 & 0 & 0 \\
& & & & 0 & 0 & 0 & 0 & 0 & 0 & 0 & 0 \\
& & & & & 0 & 0 & 0 & 0 & 0 & 0 & 0 \\
& & & & & & 1 & 0 & 0 & 0 & 0 & 0 \\
& & & & & & & 1 & 0 & 0 & 0 & 0 \\
& & & & & & & & 1 & 0 & 0 & 0 \\
& & & & & & & & & 0 & 0 & 0 \\
& & & & & & & & & & 0 & 0 \\
& & & & & & & & & & & 0
\end{array}\right]\left\{u_{e}\right\}}
\end{aligned}
$$

$[R]^{T}[R]=[I]$

$\left\{f_{e}\right\}=\left[\begin{array}{llllllllllll}f_{x 1} & f_{y 1} & f_{z 1} & M_{x 1} & M_{y 1} & M_{z 1} & f_{x 2} & f_{y 2} & f_{z 2} & M_{x 2} & M_{y 2} & M_{z 2}\end{array}\right]^{T}$

$\left\{f_{w g e}\right\}=\frac{-\hbar w l}{2}\left[\begin{array}{llllllllllll}0 & 0 & 1 & 0 & 0 & 0 & 0 & 0 & 1 & 0 & 0 & 0\end{array}\right]^{T}$

$\int_{S}(d s-d x)=s_{0}\left(1+\frac{T}{E A}\right)-l$

정립된 상미분방정식을 계산하기 위해 Newmark- $\beta$ 방법을 사 용하였다. 미소해의 수렴성에 대한 조건은 전 단계와 계산된 단 계에서의 변위와 속도의 상대오차로써 $0.01 \%$ 이내로 설정하였다.

정립된 해석기법을 기반으로 계류선 길이, 중량, 축강성을 변 화시키며 반복 계산이 수행될 수 있도록 기법을 개선하였다. 원 형시스템을 모사하기 위한 한계조건으로 구조물이 $20,40 \mathrm{~m}$ 선 미방향으로 밀려났을 때 복원력 곡선에서 $\pm 5 \%$, 장력은 초기장 력과 $20,40 \mathrm{~m}$ 선미방향 변위 상태에서 $\pm 10 \%$ 로 설정되었다. 복 
원력 곡선의 경우 부유체 운동응답에 크게 영향을 미치지 않는 영역으로 ITTC(2002)에서 정립한 오차 범위이다. 계류선에 걸리 는 장력의 경우 명확한 기준이 존재하지 않기에 설계에 적용되 는 안전계수의 범주 내에서 결정하였다.

\section{3. 수치해석 모델 및 벤치마크 테스트}

계류계 원형시스템의 개념도는 Fig. 2와 같다. 이는 흘수 $20 \mathrm{~m}$ 의 부유 구조물에 설치된 내부 터렛에 연결되어 있으며, 해저
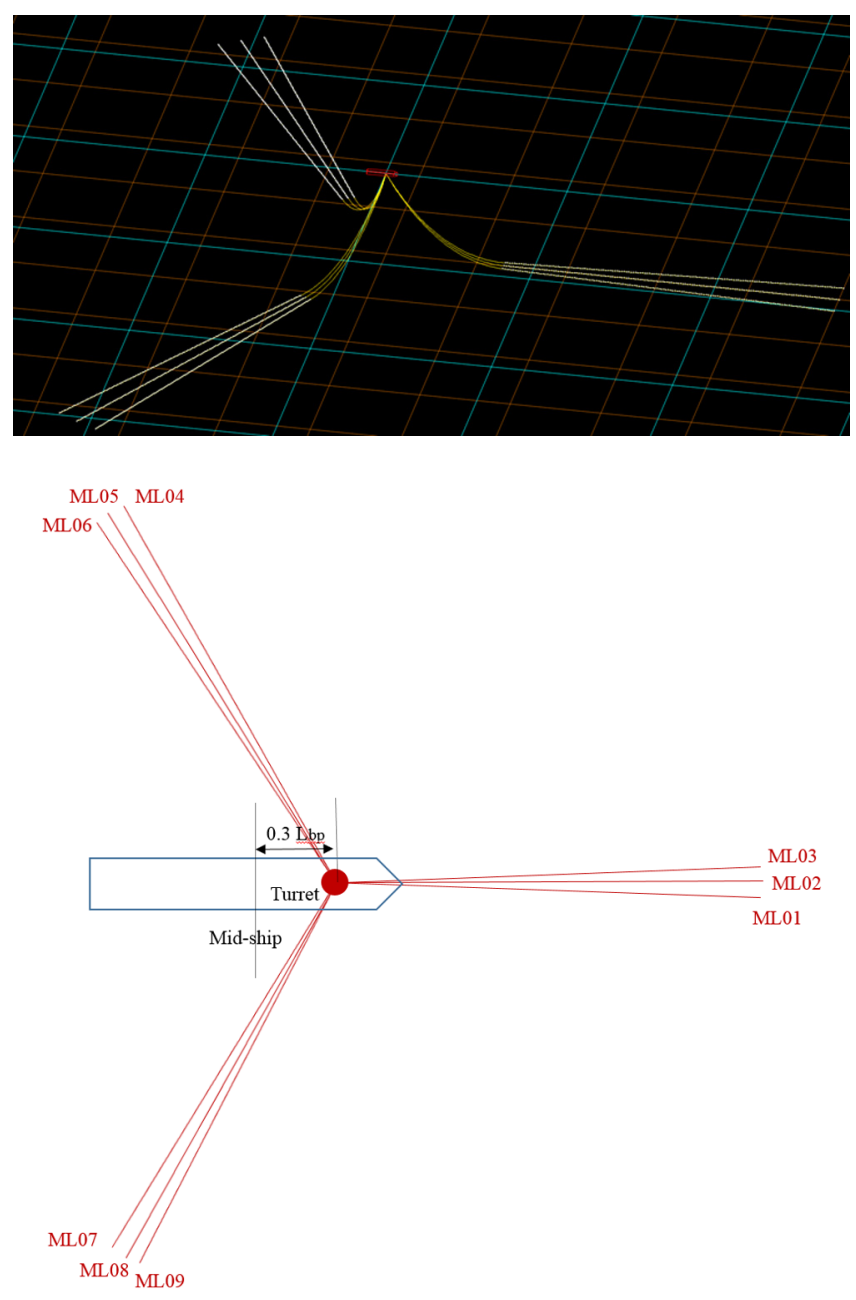

Fig. 2 Configuration of the prototype mooring lines

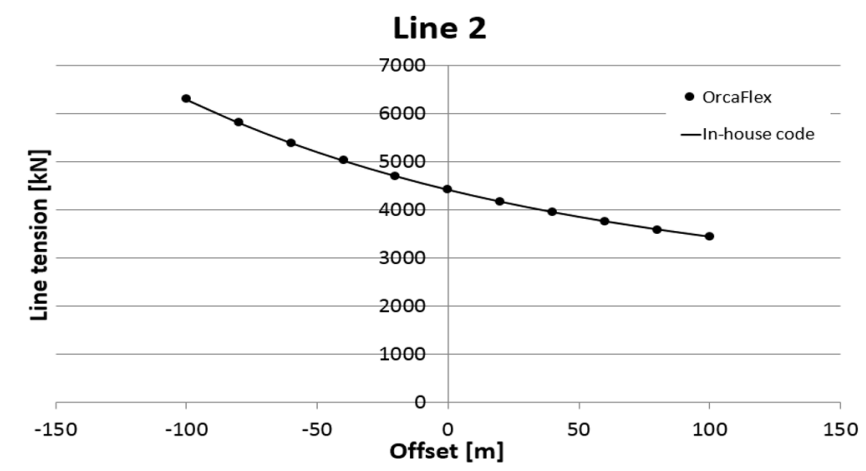

Table 1 Properties \& characteristics of the prototype mooring lines

\begin{tabular}{cc}
\hline \hline Water depth [m] & 1,000 \\
Mooring radius [m] & 5,000 \\
Mooring line length $[\mathrm{m}]$ & 5,400 \\
Weight in the water $[\mathrm{kg} / \mathrm{m}]$ & 230.15 \\
EA $[\mathrm{kN}]$ & $1.229 \mathrm{e} 06$ \\
Pre-tension $[\mathrm{kN}]$ & 4,300 \\
\hline
\end{tabular}

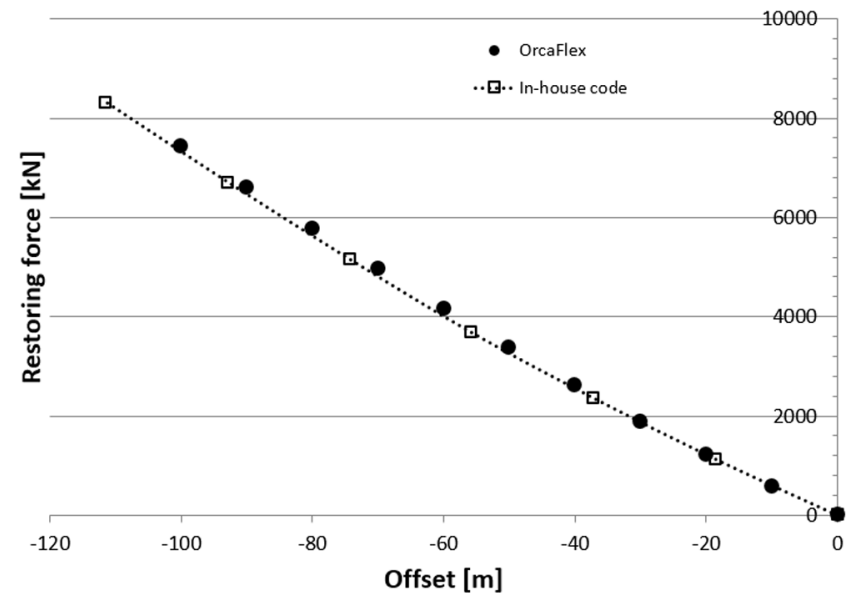

Fig. 3 Restoring curve resulted from OrcaFlex and In-house code

수심의 깊이는 $1,000 \mathrm{~m}$ 이다. 총 9 개의 현수식 계류선이며, $3 \times 3$ 배 치를 지녔다. 각 클러스터 당 3 개의 계류선이 배치되어 있으며 클러스터 내부 계류선들의 사이 각은 $3^{\circ}$, 클러스터 중심 간 사 이 각은 $120^{\circ}$ 이다. 단일 제원으로 구성되어 있으며, 계류선의 주요 제원 정보는 Table 1 과 같다.

본 해석기법에 대한 유효성 검증은 선행연구에서도 수행되었 으나(Kim et al., 2010), 본 문제에서도 유효한지를 상용프로그램 해석결과와 내부기법 해석결과를 비교함으로써 확인하였다. 상 용 프로그램은 OrcaFlex를 활용하였으며 두 기법으로 구조물의 종 방향 정적 변위 테스트(Static offset test in x-direction)를 실시 하였다. Fig. 3에는 계류선에 걸리는 복원력이, Fig. 4에는 2, 5번 계류선에 걸리는 장력이 도식화되어 있다.

Fig. 3에 보인 바와 같이 계산된 두 계류선 복원력 곡선은 상당 히 잘 일치하며, 정량적으로 구조물의 변위 $100 \mathrm{~m}$ 일 때 OrcaFlex 으로는 $7501.5 \mathrm{kN}$, 본 연구에서 개발한 해석기법으로는 $7428.5 \mathrm{kN}$

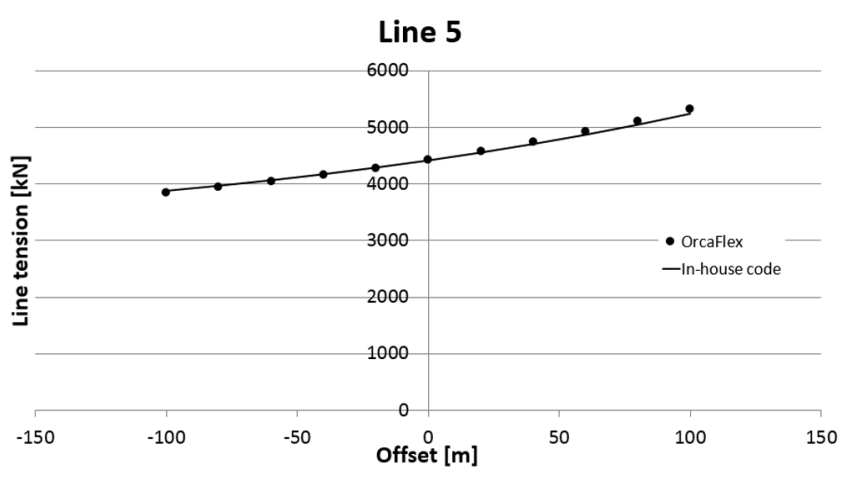

Fig. 4 Tensions of Line \#2 and \#5 resulted from OrcaFlex and In-house code 
로써 약 $1.05 \%$ 정도의 약간의 차이만 보이고 있다. 계류선에 걸리 는 장력 또한 두 해석결과가 상당히 잘 일치함에 따라 본 해석기 법의 유효성을 확인한 이후 본 계산을 수행하였다.

\section{4. 수치해석 결과}

\subsection{KRISO 해양공학수조에서의 절단계류선 모델링}

첫 번째로 KRISO 해양공학수조 조건에서 원형시스템과 정적 특성이 유사한 절단계류선의 설계가 가능한지 여부를 파악하였 다. KRISO OEB는 길이 $50.0 \mathrm{~m}$, 폭 $40.0 \mathrm{~m}$ 를 지니고 있으며, 수심 은 $3.2 \mathrm{~m}$ 조건에서 수행되었다. 모형 축척비를 $1: 60$ 으로 정할 시 본 수조에서는 수심 $192 \mathrm{~m}$ 의 해역을 모사하게 된다. 이에 따라 절 단계류 시 깊이 방향으로의 길이 비율은 수선면에서부터 해저까 지 ‘절단계류수심: 원형계류수심'은 약 1: 5.21(192m : 1000m)이 며, 폭 방향으로는 터렛 계류 중심으로부터 앵커지점까지 '절단 계류반경: 원형계류반경’은 약 1:4.17(1,200m: 5,000m)이다. Fig. 5 는 원형 계류선과 KRISO 해양공학수조에서 최대 계류반경을 반 영한 절단계류선을 동시에 표현하였다. 수조 길이와 폭의 제한으 로 인해 KRISO OEB에서는 수심 $1,000 \mathrm{~m}$ 에 투입되는 계류시스템 이 기하학적으로 상당히 다르다.

단일 제원의 계류선으로써 원형 계류선과 정적 특성이 일치 하는 절단계류선을 설계하기 위해 변화할 수 있는 인자는 계류 선의 길이, 물 속 중량, 축강성(EA)으로 축약하였다. 휨과 비틀
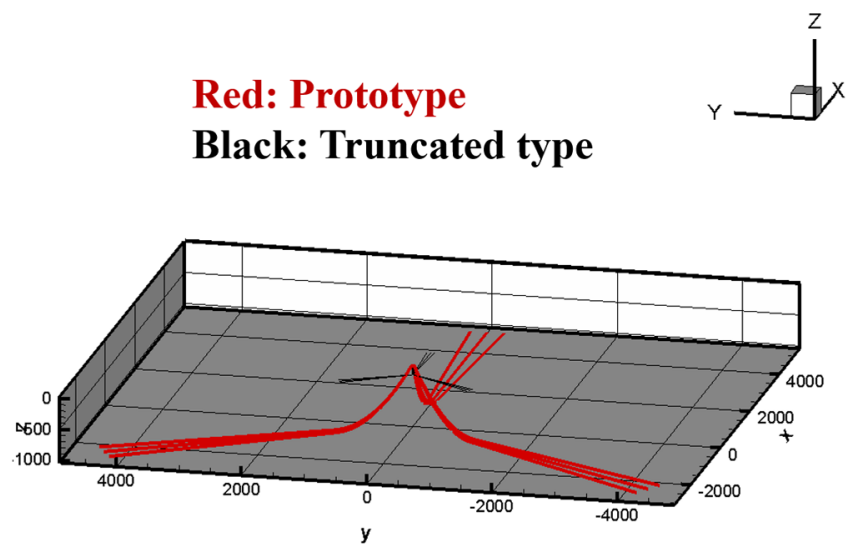

Fig. 5 Configurations of prototype mooring lines and truncated mooring lines in KRISO OEB

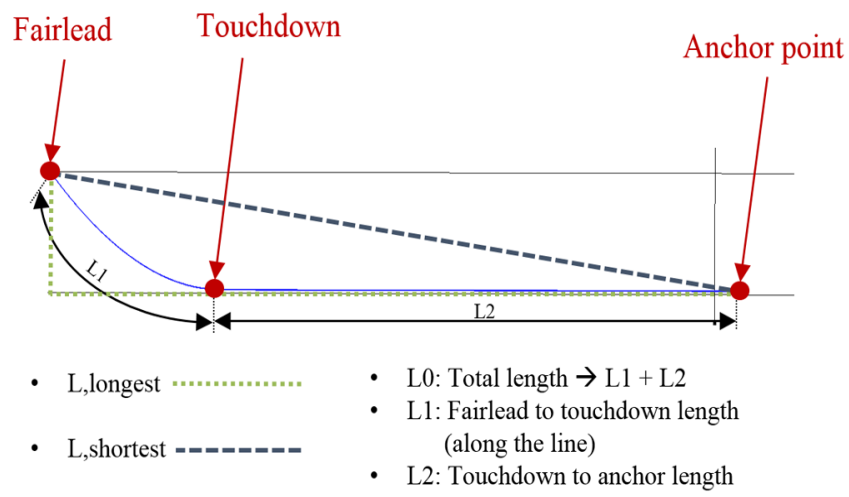

Fig. 6 Length and point definitions in a mooring line configuration
림에 의한 영향은 미미하다고 가정하였다. 먼저 한 계류선에 대 해 길이와 지점에 대한 정의는 Fig. 6과 같다. 길이의 경우 $1.2 L_{\text {shortest }} \sim 0.8 L_{\text {longest }}$ 범위 내에서 등 간격으로 총 30 개의 절 단계류선 길이를 구성하였으며, 물 속 중량과 축강성은 원형 계 류선의 $130 \% \sim 700 \%$ 사이를 $30 \%$ 간격으로 총 20 개로 나누었다. 물 속 중량과 축 강성에 대한 모형시험을 위한 현실 적용성 여 부도 고려되어야 하지만, 정보가 없는 상황에서 초기 절단계류 선 설계가 본 연구의 목적으로써, 이에 대한 범위는 가정 하에 시작되었다.

이 세 인자를 달리하면서 총 12,000 조합에 대해 절단계류선 에 대한 정적 변위 테스트를 수행한 후, 원형계류선을 모사할 수 있는 계류선이 존재하는지를 확인하였다. Table 2에는 해양 공학수조 조건에서 고려된 절단계류선들의 $\mathrm{L} 0, \mathrm{~L} 1, \mathrm{~L} 2$ 길이를 정리하였고, Fairlead로부터 Touchdown까지의 길이는 원형 계류 선과의 비율로써 정리하였다.

Table 2 Characteristic lengths of truncated mooring lines in KRISO OEB

\begin{tabular}{ccccc}
\hline \hline & L0 [m] & L1 [m] & L2 [m] & L1 / L1,prototype [\%] \\
\hline Prototype & 5400.0 & 1674.0 & 3726.0 & 100.0 \\
TRUNC01 & 1441.5 & 187.4 & 1254.1 & 11.19 \\
TRUNC02 & 1430.8 & 186.0 & 1244.8 & 11.11 \\
TRUNC03 & 1420.1 & 184.6 & 1235.5 & 11.03 \\
TRUNC04 & 1409.3 & 183.2 & 1226.1 & 10.94 \\
TRUNC05 & 1398.6 & 181.1 & 1216.8 & 10.86 \\
TRUNC06 & 1387.9 & 180.4 & 1207.5 & 10.78 \\
TRUNC07 & 1377.2 & 179.0 & 1198.2 & 10.70 \\
TRUNC08 & 1366.4 & 177.6 & 1188.8 & 10.61 \\
TRUNC09 & 1355.7 & 176.2 & 1179.5 & 10.53 \\
TRUNC10 & 1345.0 & 174.9 & 1170.2 & 10.45 \\
TRUNC11 & 1334.3 & 173.5 & 1160.8 & 10.36 \\
TRUNC12 & 1323.5 & 185.3 & 1138.2 & 11.07 \\
TRUNC13 & 1312.8 & 196.9 & 1115.9 & 11.76 \\
TRUNC14 & 1302.1 & 208.3 & 1093.8 & 12.45 \\
TRUNC15 & 1291.3 & 219.5 & 1071.8 & 13.11 \\
TRUNC16 & 1280.6 & 243.3 & 1037.3 & 14.53 \\
TRUNC17 & 1269.9 & 266.7 & 1003.2 & 15.93 \\
TRUNC18 & 1259.2 & 302.2 & 957.0 & 18.05 \\
TRUNC19 & 1248.4 & 349.6 & 898.8 & 20.88 \\
TRUNC20 & 1237.7 & 433.2 & 804.5 & 25.88 \\
TRUNC21 & 1227.0 & 564.4 & 662.6 & 33.72 \\
TRUNC22 & 1216.3 & 802.8 & 413.5 & 47.95 \\
TRUNC23 & 1205.5 & 1205.5 & 0.0 & 72.01 \\
TRUNC24 & 1194.8 & 1194.8 & 0.0 & 71.37 \\
TRUNC25 & 1184.1 & 1184.1 & 0.0 & 70.73 \\
TRUNC26 & 1173.3 & 1173.3 & 0.0 & 70.09 \\
TRUNC27 & 1162.6 & 1162.6 & 0.0 & 69.45 \\
TRUNC28 & 1151.9 & 1151.9 & 0.0 & 68.81 \\
TRUNC29 & 1141.2 & 1141.2 & 0.0 & 68.17 \\
TRUNC30 & 1130.4 & 1130.4 & 0.0 & 67.53 \\
\hline & & & &
\end{tabular}




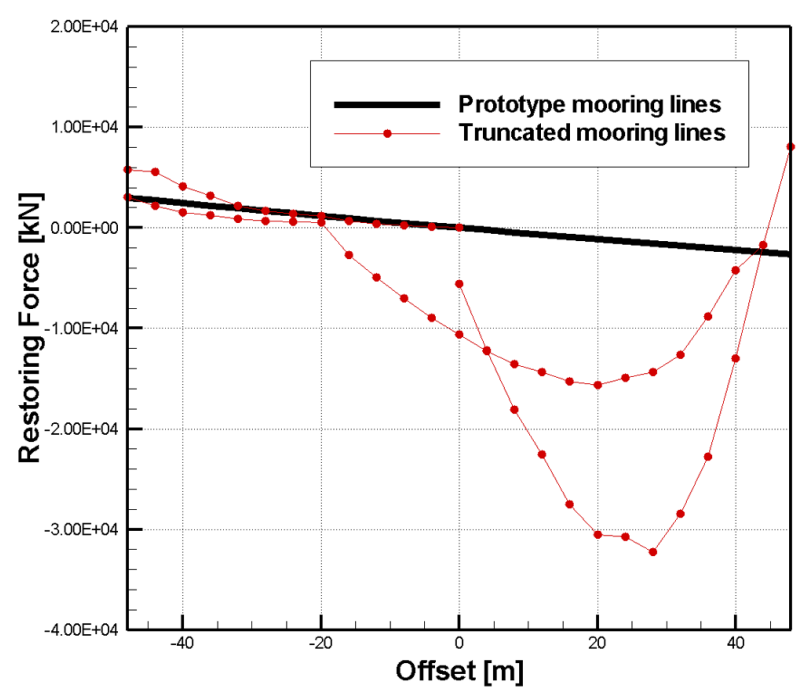

Fig. 7 Restoring force of one matched case with longest mooring lines in KRISO OEB circumstance

해석 수행 시 원형시스템과 목표 지점인 $-20.0 \mathrm{~m},-40.0 \mathrm{~m}$ 중 한 지점에서 같은 복원력을 지닌 계류선이 몇 경우 존재하지만, 전 체 복원력은 원형시스템과 상당한 차이를 보이고 있었다. 이를 보다 면밀히 살펴보기 위해 특정 지점에서 복원력이 일치하는 경우, 전체 복원력 곡선을 Fig. 7에 나타내었다. 여기서 절단계 류선은 TRUNC01에 물 속 중량은 원형계류선에 비해 2.2배, 축 강성은 1.9 배 증가시킨 경우의 결과이다. 해석 시 $0 \mathrm{~m} \rightarrow-48 \mathrm{~m}$ $\rightarrow 0 \mathrm{~m} \rightarrow 48 \mathrm{~m} \rightarrow 0 \mathrm{~m}$ 방향으로 계류선 Fairlead 부분을 이동시 켰으며, 간격은 $4 \mathrm{~m}$ 이다. 따라서 한 변위에 해당하는 복원력은 두 개가 나오게 된다.

절단계류선에 의한 복원력은 선미방향으로 $20.0 \mathrm{~m}$ 밀려난 지점 에는 오차 범위 내의 값을 지니고 있지만, 그 외 변위 구간에서 상당히 다른 경향을 보이고 있다. 또한 동일한 변위에서의 결과 값이 다르게 나타내며, 특히 선수 방향으로의 변위에서는 원형시 스템에 비해 상당히 큰 값으로 선미를 향해 복원력을 전달해준 다. 이보다 길이가 짧은 계류선에 대한 해석 시(TRUNC02 TRUNC30) $-48.0 \mathrm{~m}$ 최대 변위에 도달하기 전에 계산이 이루어지 지 않고 수치해석이 발산했다. 이는 깊이 방향으로 상당히 짧아 짐에 따라 Fairlead에서의 상대적인 과도한 변위에 따라 압축력까
지 모사하지 못한 현 해석기법에서는 해석해가 발산하는 원인이 되는 것으로 판단되었다.

길이 방향으로만 절단계류선의 적용가능성을 검토할 시 $1: 8$ 까 지의 깊이 비율까지는 선행연구에서 절단계류선을 확보할 수 있 었으나(Baarholm et al., 2007), 수조 폭을 고려한다면 그 보다 더 좁은 범위여야만 절단계류선 모사가 가능함을 확인하였다. 따라 서 단일 제원의 절단계류선으로는 심해 계류선 모사가 상당히 어 렵기에 현재 대전 해양공학수조에서 심해 계류시스템 평가 시험 시 Anchor point에 스프링을 설치하거나 Actuator를 설치하여 차 이를 줄여나가는 노력이 이루어지는 이유이다.

\section{$4.2 \mathrm{KRISO}$ 심해공학수조에서의 절단계류선 모델링}

다음으로 KRISO 심해공학수조 조건에서 동일한 계산이 수행 되었다. KRISO DOEB는 길이 $100.0 \mathrm{~m}$, 폭 $50.0 \mathrm{~m}$ 를 지니고 있으며, 수심은 $15.0 \mathrm{~m}$ 조건에서 수행되었다. 동일한 모형 축척비 $1: 60$ 을 적용하였으며, 절단 계류 시 깊이 방향으로는 수선면에서부터 해 저까지 ‘절단계류수심: 원형계류수심'은 1:1.11(900m: $1000 \mathrm{~m})$, 폭 방향으로는 터렛 계류 중심으로부터 앵커 지점까지 '절단계류반 경: 원형계류반경'은 $1: 3.33(1,500 \mathrm{~m}: 5,000 \mathrm{~m})$ 의 길이 비를 가지고 있다. Fig. 8에는 KRISO DOEB 조건에서 고려한 모든 절단계류 선을 원형시스템과 동시에 표시하였다. 또한 Table 3에는 Table 2 와 마찬가지로 심해공학수조 조건에서 고려된 절단계류선들의 길이 정보를 나타내었다.

총 20 개의 계류선 길이를 고려하였으며, $1.1 L_{\text {shortest }} \sim 0.75 L_{\text {longest }}$ 사이를 균등하게 나누어서 계류선 길이를 결정하였다. 물 속 중 량의 경우 TRUNC01 TRUNC10까지 총 10 개의 절단계류선은 원형시스템에 비해 $130 \sim 700 \%$ 사이를 $30 \%$ 간격으로, TRUNC11 TRUNC20까지 나머지 10개의 절단계류선은 원형시스템에 비해 $110 \sim 300 \%$ 사이를 $10 \%$ 간격으로 나누었다. 축 강성은 20 개 절단 계류선 모두 원형시스템에 비해 $130 \sim 700 \%$ 사이를 $30 \%$ 간격으로 모든 경우를 균등하게 나누었다. 이로써 총 8,000 개의 인자 조 합에 대한 해석이 수행되었다.

가장 긴 절단계류선 길이를 지닌 TRUNC01 해석 시 물 속 중 량과 축강성을 변화시키며 계산된 복원력의 원형계류선에 의한 복원력과의 비율은 Fig. 9과 같다. 여기서 Ratio는 원형 계류선 에 의한 복원력 대비 절단 계류선에 의한 복원력으로써, $100 \%$ 는 두 물리량이 같음을 의미한다. 이 계류선은 가장 긴 계류선
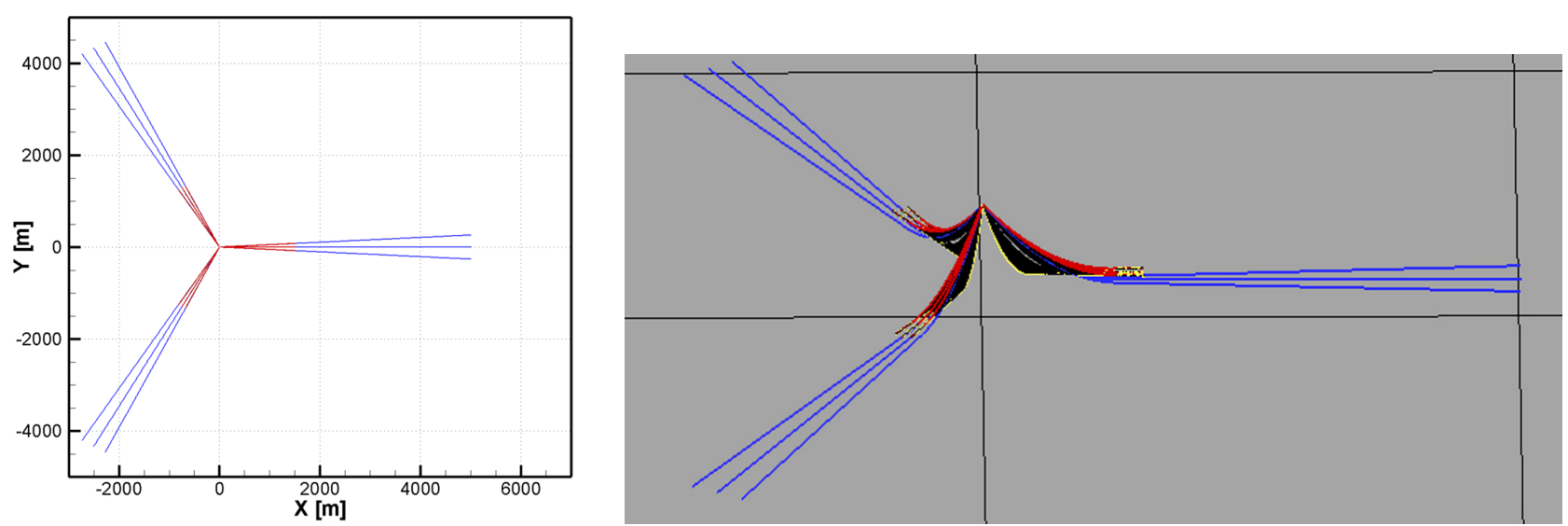

Fig. 8 Truncated mooring line configurations in KRISO DOEB 
Table 3 Characteristic lengths of truncated mooring lines in KRISO DOEB

\begin{tabular}{lcccc}
\hline \hline & L0 [m] & L1 [m] & L2 [m] & L1 / L1,prototype [\%] \\
\hline Prototype & 5400.0 & 1674.0 & 3726.0 & 100.0 \\
TRUNC01 & 2088.0 & 1002.2 & 1085.8 & 59.87 \\
TRUNC02 & 2073.1 & 1036.6 & 1036.6 & 61.92 \\
TRUNC03 & 2058.2 & 1049.7 & 1008.5 & 62.71 \\
TRUNC04 & 2043.3 & 1062.5 & 980.8 & 63.47 \\
TRUNC05 & 2028.4 & 1075.1 & 953.3 & 64.22 \\
TRUNC06 & 2013.6 & 1107.5 & 906.1 & 66.16 \\
TRUNC07 & 1998.7 & 1139.3 & 859.4 & 68.06 \\
TRUNC08 & 1983.8 & 1150.6 & 833.2 & 68.73 \\
TRUNC09 & 1968.9 & 1181.3 & 787.6 & 70.57 \\
TRUNC10 & 1954.0 & 1211.5 & 742.5 & 72.37 \\
TRUNC11 & 1918.0 & 1285.1 & 632.9 & 76.77 \\
TRUNC12 & 1908.4 & 1316.8 & 591.6 & 78.66 \\
TRUNC13 & 1898.8 & 1348.1 & 550.7 & 80.53 \\
TRUNC14 & 1889.1 & 1379.0 & 510.1 & 82.38 \\
TRUNC15 & 1879.5 & 1390.8 & 488.7 & 83.08 \\
TRUNC16 & 1869.9 & 1439.8 & 430.1 & 86.01 \\
TRUNC17 & 1860.2 & 1469.6 & 390.6 & 87.79 \\
TRUNC18 & 1850.6 & 1499.0 & 351.6 & 89.55 \\
TRUNC19 & 1841.0 & 1528.0 & 313.0 & 91.28 \\
TRUNC20 & 1831.4 & 1575.0 & 256.4 & 94.09 \\
\hline
\end{tabular}

이면서 축 강성에 의한 변화는 상대적으로 미미한 가운데 물 속 중량에 의한 복원력의 변화가 지배적으로 나타났다. 이는 현 수식 계류선에서 두드러진 특성으로 원형 시스템과 유사한 특 성을 만족함을 확인하였다. 또한 절단계류선에 의한 복원력이 원형 시스템의 그것과 95 105\%범위 내로 계산되는 물 속 중량 및 축강성 조합도 400 개의 계산 중 37 개가 도출되었다. 이 중 물 속 중량이 3.7 배 일 때 17 개, 4.0 배일 때 20 개가 오차 범위 내로 계산되었다. 복원력이 원형시스템과 유사한 절단계류선들 의 복원력 곡선 중 두 경우를 Fig. 10 에 나타내었다. 검은색 실

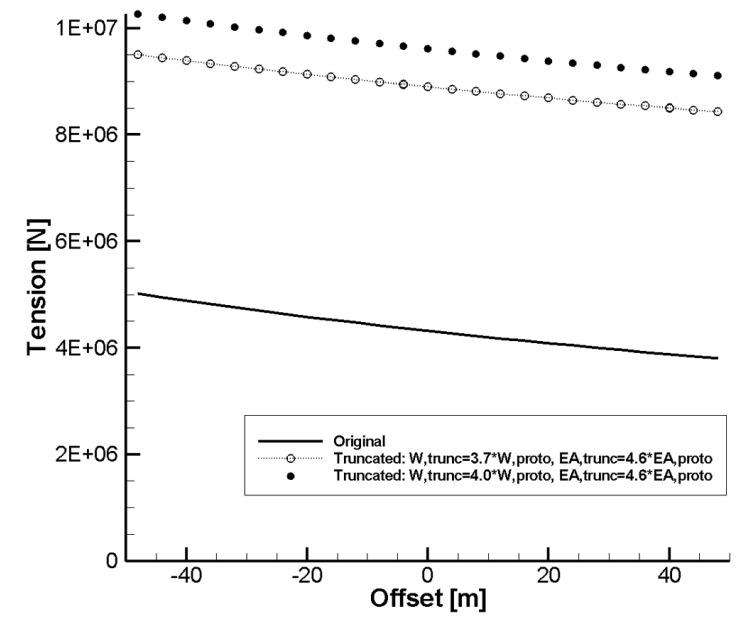

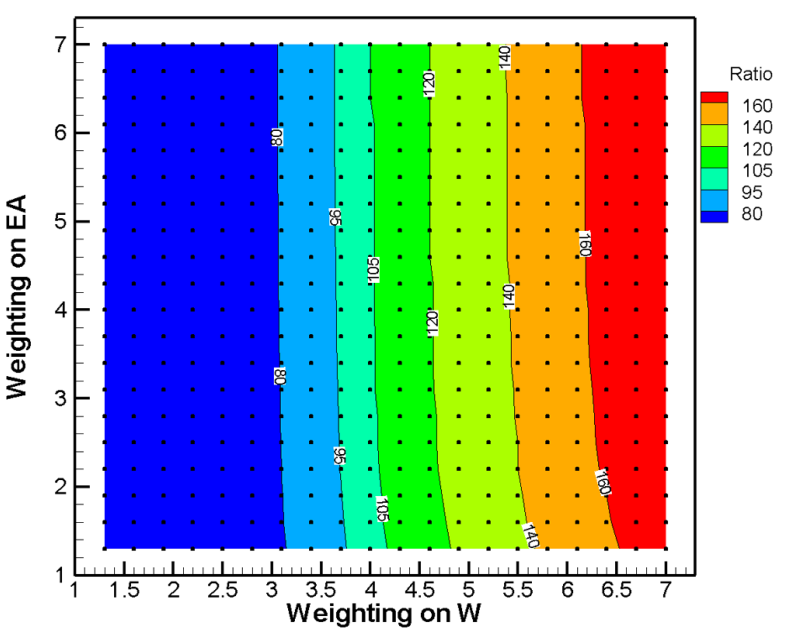

Fig. 9 Restoring forces ratio with respect to weight and EA: TRUNC01 simulation

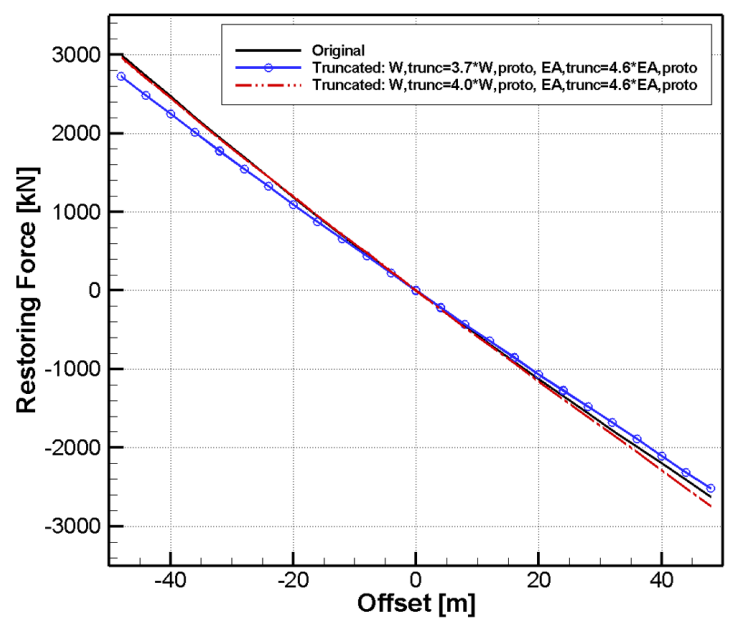

Fig. 10 Restoring force of matched truncated mooring line cases: TRUNC01 simulation

선이 원형시스템의 복원력이고 파란색 실선과 원형 마크가 원 형시스템에 비해 물 속 중량은 3.7배, 축 강성은 4.6배한 절단계 류선의 해석결과이고 붉은색 드문 점선이 가 있는 실선이 원형

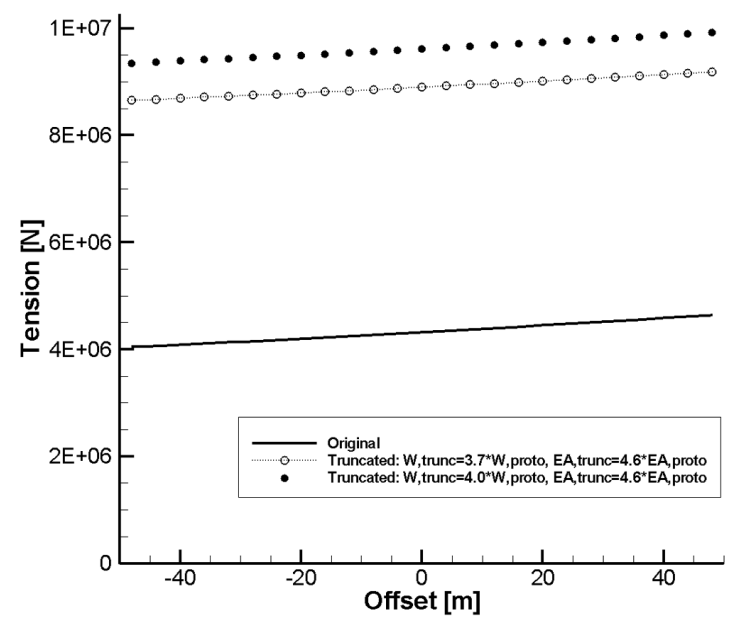

Fig. 11 Line tensions of \#2 (left) and \#5 (right) of matched truncated mooring line cases: TRUNC01 simulation 


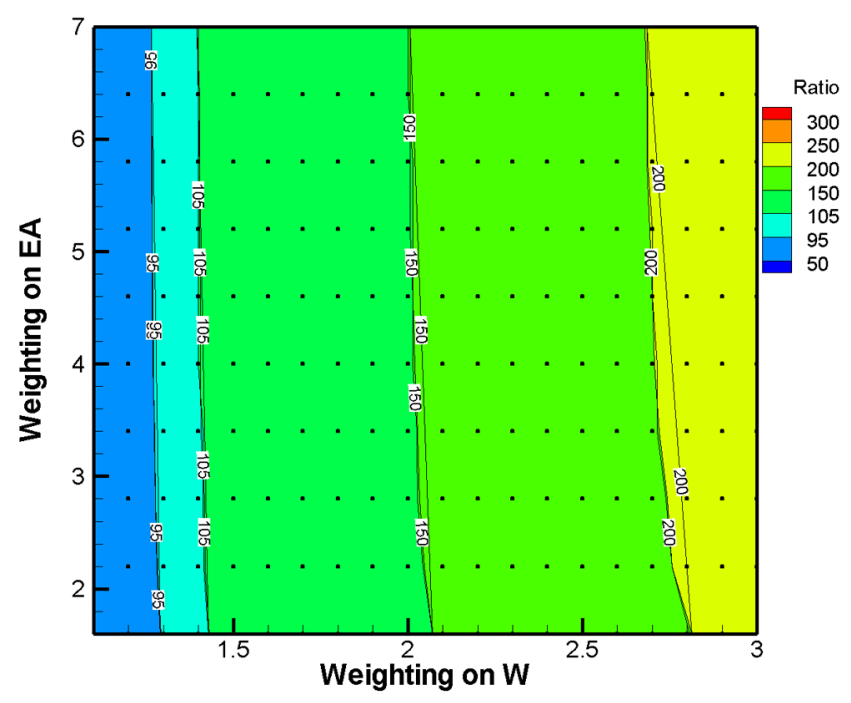

Fig. 12 Restoring forces ratio with respect to weight and EA: TRUNC11 simulation

시스템에 비해 물 속 중량은 4.0 배, 축 강성은 4.6 배한 절단계류 선의 해석결과이다. 대체적으로 선형적인 경향을 보이고 있으 며, 물 속 중량이 다름에 따라 약간의 기울기 차이가 존재한다.

복원력 곡선이 오차 범위 내에서 일치하는 두 절단계류선들 에 걸치는 장력 또한 Fig. 11에 도식화 하였다. 물 속 중량이 $370 \%$ 일 때보다 $400 \%$ 일 때 전체적으로 증가하는 경향을 보이 며, 전자는 원형 시스템에 비해 약 2.07배, 후자는 2.24배 큰 값 이 계산된다. KRISO DOEB 조건에서 고려한 절단계류선 중 가 장 긴 후보군의 경우 전체 복원력을 맞추는 것은 용이하나 이 경우 계류선에 걸리는 장력은 상당한 차이가 남을 확인하였다.

Fig. 12에는 TRUNC11 절단계류선에 대한 원형계류선에 의한 복원력 대비 절단계류선에 의한 복원력을 도식화하였다. TRUNC11 의 경우 물 속 중량이 원형시스템 대비 $130 \%, 140 \%$ 일 시 계산된 복원력이 원형 시스템의 그것과 잘 일치함을 확인하였으며, 오차 범위 내로 들어온 절단계류선의 복원력 곡선 중 대표적인 두 곡선 은 원형시스템의 그것과 함께 Fig. 13에 나타내었다. Fig. 10과 유

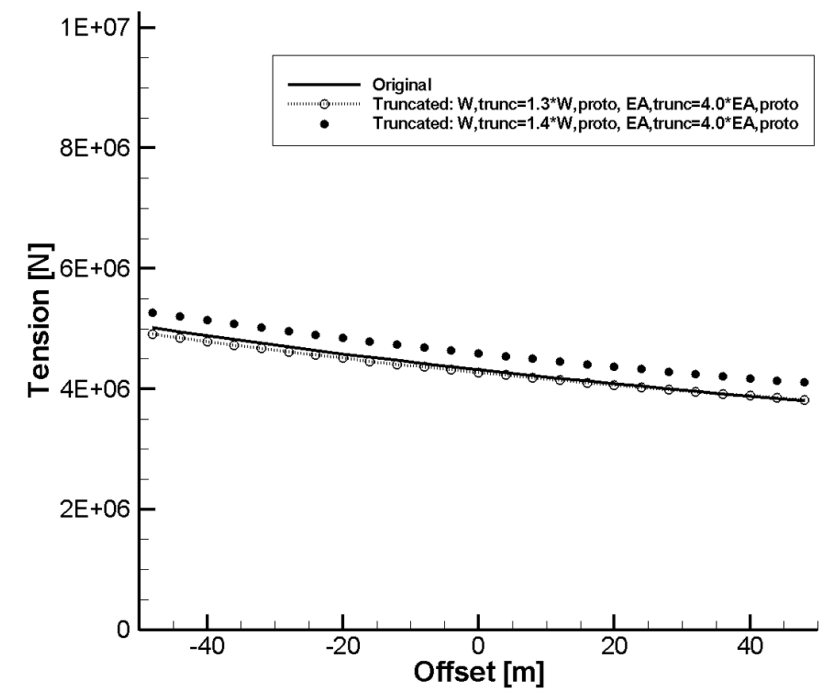

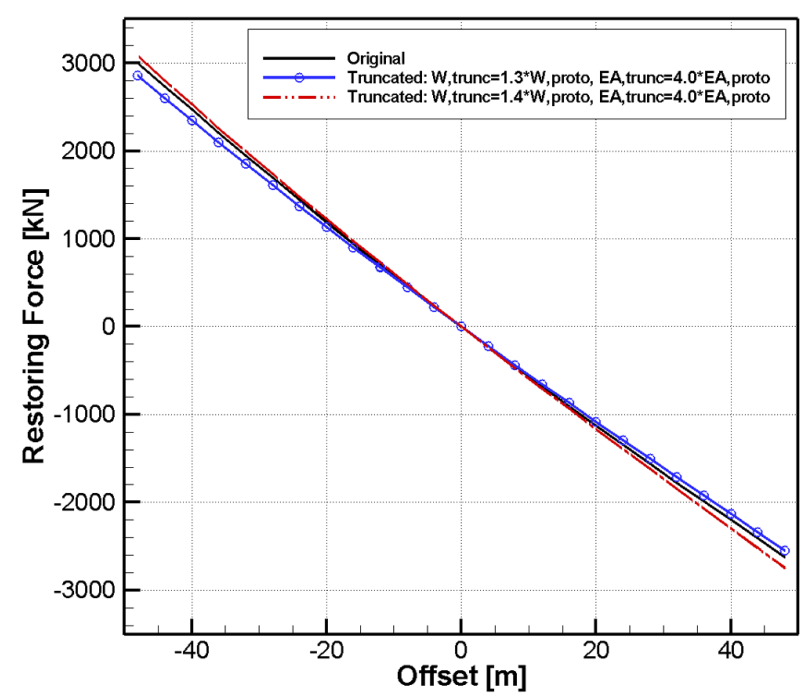

Fig. 13 Restoring force of matched truncated mooring line cases: TRUNC11 simulation

사하게 중량의 차이에 따른 기울기 차이가 존재하며, 보다 더 원 형시스템과 유사한 결과는 물 속 중량이 $140 \%$ 일 때였다.

반면 이 경우들에서의 계류선에 걸리는 장력의 변화는 Fig. 14 에 나타내었다. 계류선에 걸리는 장력의 경우 물 속 중량이 $130 \%$ 일 때는 약 0.99 배, 물 속 중량이 $140 \%$ 일 때는 약 1.07 배로 나타나서 계류선에 걸리는 장력의 상사를 맞추기 위해서는 $130 \%$ 물 속 중량이 더 적합하다는 결론이 나왔다. 따라서 물 속 중량을 $130 \sim 140 \%$ 사이에서 부유체에 걸리는 복원력과 계류 선에 걸리는 장력 둘 다 일정 오차 내에 만족하는 절단계류선 설계가 가능한 것으로 사료된다.

마지막으로 KRISO 심해공학수조 조건에서 수심 $1,000 \mathrm{~m}$ 에 투 입되는 원형시스템과 정적 유사성을 지닌 절단계류선의 결과는 Table 4에 정리되었다. 계산시간은 최소 4790.64초에서부터 최 대 6321.93초 사이였으며, 각 경우마다 400개의 물 속 중량, 축 강성 인자가 조합되었다.

유한요소법에 기반한 해석기법에서 완화 인자(Relaxation factor),

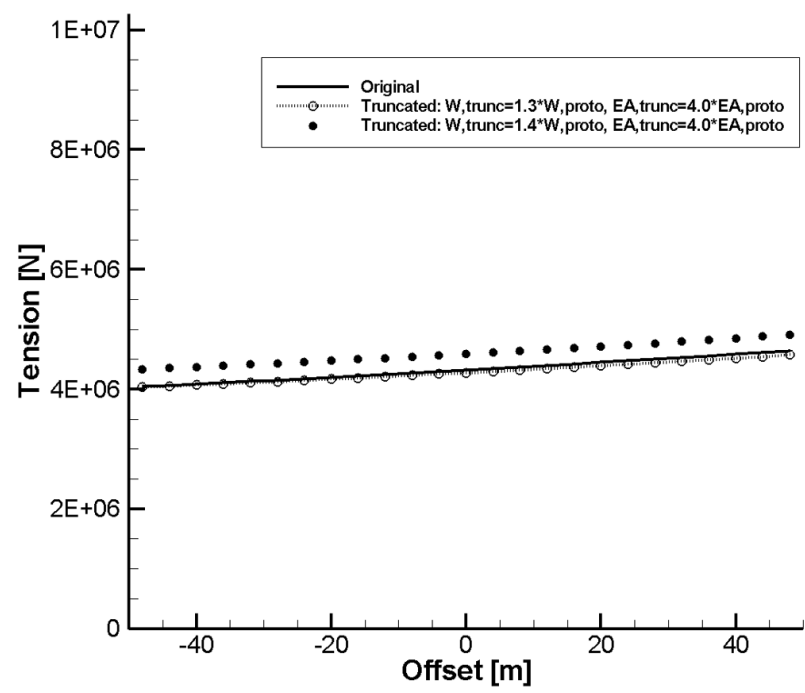

Fig. 14 Line tensions of \#2 (left) and \#5 (right) of matched truncated mooring line cases: TRUNC11 simulation 
Table 4 Overview of truncated mooring line matching simulations in KRISO DOEB circumstance

\begin{tabular}{|c|c|c|c|c|c|}
\hline & $\begin{array}{c}\text { Calculation time } \\
{[\mathrm{sec}]}\end{array}$ & $\begin{array}{c}\text { Number of } \\
\text { diverged cases }\end{array}$ & $\begin{array}{l}\text { Number of } \\
\text { restoring curve } \\
\text { matched cases }\end{array}$ & $\begin{array}{c}\text { Number of } \\
\text { pretension } \\
\text { matching cases }\end{array}$ & $\begin{array}{c}\text { Number of } \\
\text { tension curve } \\
\text { matching cases }\end{array}$ \\
\hline TRUNC01 & 6321.93 & 2 & 37 & 0 & 0 \\
\hline TRUNC02 & 5787.22 & 2 & 33 & 0 & 0 \\
\hline TRUNC03 & 5303.47 & 0 & 28 & 0 & 0 \\
\hline TRUNC04 & 5758.61 & 0 & 20 & 0 & 0 \\
\hline TRUNC05 & 5475.34 & 1 & 20 & 0 & 0 \\
\hline TRUNC06 & 5480.80 & 0 & 19 & 0 & 0 \\
\hline TRUNC07 & 5517.12 & 3 & 19 & 0 & 0 \\
\hline TRUNC08 & 5627.92 & 0 & 4 & 0 & 0 \\
\hline TRUNC09 & 4945.62 & 1 & 20 & 0 & 0 \\
\hline TRUNC10 & 4790.64 & 0 & 0 & 0 & 0 \\
\hline TRUNC11 & 6200.36 & 2 & 36 & 34 & 32 \\
\hline TRUNC12 & 6107.48 & 1 & 38 & 37 & 37 \\
\hline TRUNC13 & 5956.44 & $\mathbf{0}$ & 20 & 18 & 17 \\
\hline TRUNC14 & 5884.04 & 1 & 20 & 20 & 17 \\
\hline TRUNC15 & 5736.00 & 0 & 0 & 0 & 0 \\
\hline TRUNC16 & 5376.88 & 0 & 0 & 0 & 0 \\
\hline TRUNC17 & 5131.32 & 0 & 0 & 0 & 0 \\
\hline TRUNC18 & 5169.82 & 0 & 0 & 0 & 0 \\
\hline TRUNC19 & 5154.28 & 0 & 0 & 0 & 0 \\
\hline TRUNC20 & 5065.44 & 0 & 0 & 0 & 0 \\
\hline
\end{tabular}

허용오차(Tolerance) 등 문제마다 약간씩 변화시켜야 할 인자들을 하나로만 수행함에 따라 경우에 따라서 해가 발산하는 경우도 있으 나 전체 해석 중 차지하는 비중이 미미했다. TRUNC14 이전까지는 복원력을 상사시킨 경우도 다수 존재하나, TRUNC11(L0: 1918.0m) TRUNC14(L0: 1889.1m) 경우에서만 계류선에 걸리는 장력까지 상사시킨 경우가 도출되었다. 이 때 Fairlead부터 Touchdown까지의 거리는 원형 계류선 대비 76.77 82.38\%에 해당하며, 물 속 중량은 $110 \sim 140 \%$ 범위 내에서 상사된 계류선이 나타났다. 또한 TRUNC15 이후부터는 해당 계산에서 고려한 물 속 중량 $110 ~ 300 \%$ 내에서는 복원력이 오차 범위 내에 계산되는 해석조건이 존재하지 않은 것을 확인했다. 이는 전체 길이(L2)가 너무 짧아질 시 현수식 계류선에서 인장식 계류선으로 특성이 변하게 되며, 이 특성 변화로 인해 복원 력 상사가 불가능해지는 것으로 사료된다.

\section{5. 결 론}

본 논문에서는 실제 모형시험을 통한 심해에 투입되는 계류 선의 안정성 평가를 위한 절단계류선 설계가 수치적으로 연구 되었다. 선박해양플랜트연구소 해양공학수조와 심해공학수조에 서 수심 $1,000 \mathrm{~m}$ 에 투입되는 현수식 계류선과 정적 특성이 맞는 계류선을 찾기 위해 계류선 길이, 물 속 중량, 축 강성 세 값을 조합하면서 넓은 범위에서의 절단계류선 모사 가능성을 확인하 였다. 이를 통해 다음의 결론을 도출하였다.

(1) 해양공학수조 조건에서는 길이와 폭의 제약이 큼에 따라
절단계류선의 길이 자체가 상당히 짧아지게 된다. 이에 실제 해 양구조물과 동일한 정적 변위 테스트 시 수치해석 값 자체가 상당히 불안정하며, 원형 계류선과 정적 특성이 유사한 모형시 험용 계류선을 찾을 수 없다. 단일 제원을 이용한 절단계류선 설계는 한계가 있으며, 두 가지 이상의 제원을 활용한 방법(Kim et al., 2014)이나 끝단 스프링, 능동적 가진 장치 설치 등의 대안 이 요구된다.

(2) 심해공학조건에서는 Fairlead부터 Touchdown 지점까지의 거리(L1)가 원형시스템에 일정 수준 이상 근접하면 구조물에 걸 리는 복원력과 계류선에 걸리는 장력을 동시에 만족하는 절단 계류선 모사가 가능하다. 단, 일정 수준 이상 길어지면 자연적 으로 전체 계류선 길이가 짧아지면서 계류계 특성 자체가 현수 식 계류선에서 인장 계류선으로 넘어가게 되고, 이런 특성 변화 로 복원력 상사가 이뤄지지 않았다.

(3) 현재 해석기법을 기반으로 단일 제원을 이용한 초기 수조 시험용 절단계류선 설계가 가능하며, 향후에는 보다 다양한 인 자들에 대한 고려, 유전알고리즘 적용을 통한 계산시간의 단축, 두 가지 제원 이상을 활용한 절단계류선 해석 기법 정립 등을 적용할 수 있으며 최종적으로는 동적 상사성을 만족하는 절단 계류선 설계가 요구된다.

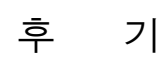

본 연구는 해양수산부 국가연구개발사업 심해공학수조 운용 
을 위한 연구인프라 구축 및 심해플랜트 Pre-FEED 원천핵심기 술개발(PMS3740)' 및 한국해양과학기술원 부설 선박해양플랜트 연구소 내부 주요사업 '심해공학수조 기초 운용기술 개발 (PES9080)'에서 수행된 연구결과 중 일부임을 밝히며, 연구비 지원에 감사드립니다.

\section{References}

Baarholm, R., Stansberg, C.T., Fylling, I., Lee, M.Y., Ma, W., 2007, A Robust Procedure for Ultra Deepwater Model Testing, Proc. of $17^{\text {th }}$ International Offshore and Polar Engineering Conference, Lisbon Portugal, 2229-2238.

Bernitsas, M.M., Choi, H.S., Crudu, L., Hirata, K., Incecik, A., Kinoshita, T., Moxnes, S., 1999, The Specialist Committee on Deep Water Mooring: Final Report and Recommendations to the $22^{\text {nd }}$ ITTC. Proceedings of the $22^{\text {nd }}$ International Towing Tank Conference, Shanghai, China, 1-24.

International Towing Tank Conference (ITTC), 2002, ITTC Recommended Procedures and Guidelines: Procedure 7.5-02-07-03.4. Stationary Floating Systems Hybrid Mooring Simulation Model Test Experiments, Rev. 00.

International Towing Tank Conference (ITTC), 2005, ITTC
Recommended Procedures and Guidelines: Procedure 7.5-0207-03.5. Truncation of Test Models and Integration with Numerical Simulations, Rev. 00.

Kim, B.W., Sung, H.G., Hong, S.Y., Jung, H.J., 2010. Finite Element Nonlinear Analysis for Catenary Structure Considering Elastic Deformation. Computer Modeling in Engineering \& Sciences, 63(1), 29-45.

Kim, B.W., Sung, H.G., Kim, J.H., Hong, S.Y., 2013. Comparison of Linear Spring and Nonlinear FEM Methods in Dynamic Coupled Analysis of Floating Structure and Mooring System, Journal of Fluids and Structures, 42, 205-227.

Kim, Y.H., Cho, S.K., Sung, H.G., Seo, J.H., Suh, Y.S., 2014, Numerical Study on Designing Truncated Mooring Lines for FPSO Stability Analysis. Journal of Ocean Engineering and Technology, 28(5), 387-395.

Stansberg, C.T., Ormberg, H., Oritsland, O., 2002, Challenges in Deep Water Experiments: Hybrid Approach, Journal of Offshore Mechanics and Arctic Engineering, 124, 90-96.

Waals, O.J., van Dijk, R.R., 2004, Truncation Methods for Deep Water Mooring Systems for a catenary moored FPSO and a Semi Taut Moored Semi Submergible. Deep Offshore Technology Conference, New Orleans USA, Paper No. 24-1. 